\title{
Improving ant-surveillance trap design to reduce competitive exclusion
}

\author{
L.D. Stringer ${ }^{1}$, D.M. Suckling ${ }^{1}$, L.T.W. Mattson ${ }^{2}$ and L.R. Peacock ${ }^{3}$ \\ ${ }^{1}$ The New Zealand Institute for Plant E Food Research Limited, Private Bag 4704, \\ Christchurch Mail Centre, Christchurch 8140, New Zealand \\ ${ }^{2}$ AsureQuality Limited, Private Bag 2019, New Plymouth 4342, New Zealand \\ ${ }^{3}$ MAF Biosecurity New Zealand, PO Box 2526, Wellington 6011, New Zealand \\ Corresponding author: lloyd.stringer@plantandfood.co.nz
}

\begin{abstract}
The National Invasive Ant Surveillance is conducted annually around ports and other high-risk areas to detect new ant incursions into New Zealand. Currently, non-sticky food-baited vials are used to trap ants. The ability of a sticky bait trap to trap multiple ant species at baits was tested, under the hypothesis that a sticky trap would reduce the role of competitive exclusion at food sources, a drawback of food baiting. Furthermore, the role of food type, sugar, protein and a combination of both foods, on ant catch was examined. Although only $4 \%$ of traps caught multiple species, this incidence was five times greater in the sticky-bait than food-only vials. The combined food source traps caught ants more often than the single food source traps. The refinement of ant monitoring traps will aid surveillance managers in the future.
\end{abstract}

Keywords food attractant, trapping, Formicidae, surveillance, ants.

\section{INTRODUCTION}

There is growing evidence that ant species that initially appear innocuous, apparently not warranting control, may subsequently become a pest (Crooks \& Soulé 1999). This may occur through a rapid change within the species (Whitney \& Gabler 2008; Sagata \& Lester 2009), invasion of a more aggressive population of the same species (Abbott et al.2007) or improvement in food sources such as sugar-excreting homopterans (O’Dowd et al. 2003; Abbott \& Green 2007; Simberloff 2006). Other species simply appear to find a niche (Crooks 2005; Stringer \& Lester 2008) or for no apparent reason die off (Simberloff \& Gibbons 2004).
In recent years MAF Biosecurity New Zealand (MAFBNZ) has reduced ant contamination rates of containers into New Zealand by shifting risk management offshore (Nendick et al. 2006). An annual National Invasive Ant Surveillance (NIAS) programme is conducted at ports of entry and other high-risk areas, such as transitional facilities (container de-vanning sites), to detect ants at an early stage of incursion (e.g. Ward et al. 2010). There is a widely held consensus that early detection and rapid response offer the best opportunities to prevent the establishment of invasive species (Crooks 2005; Hulme 2006). The NIAS is designed to reduce the impact of 
new unwanted invasive ants, such as, but not limited to, Solenopsis species (fire ants).

Ant surveillance in New Zealand is currently undertaken using baits of sugar- (30\% sugar water on a cotton ball) and protein- (peanut butter in soya oil with raw sausage meat) based food sources offered in $60 \mathrm{ml}$ plastic vials, usually in place for 2 hours. The type of food offered in a bait has a significant influence on the ant species detected (Abril et al. 2007). Food-baited traps are relatively inexpensive, but underestimate species diversity in comparison with the more labour-intensive pitfall trapping (Delabie et al. 2000), in part because behaviourally or numerically dominant species may usurp others from a food bait (Fellers 1987; McGlynn 1999, 2000). Importantly, this means that species of interest to surveillance managers may not appear in bait samples if they are less abundant or behaviourally subdominant to other species in the area (Davidson 1998; Sagata \& Lester 2009). Some of this bias may be overcome by offering different bait types separately (Palmer 2003).

A modified bait trap that includes a sticky surface was developed by Charles et al. (2002) to combine the ease of use of bait traps with the more representative sampling of pitfall traps (Delabie et al. 2000). Stringer et al. (2009) reported results on ant species catch by sticky trap for no additional trapping effort. In the current work, the effect of trap design and food type on ant species catch was investigated. The relative attractiveness of protein, sugar and combined baits to ants was measured during the 2007-2008 NIAS in New Zealand. It was hypothesised that (a) there would be a greater frequency of multiple species caught in the sticky trap than in the non-sticky traps and (b) the combined food source would be the best ant attractant because the dietary requirements would be met for more species at the combined bait than at the single food resources.

\section{MATERIALS AND METHODS}

The trial was conducted during December 2007 (summer) in three spatially separate field sites (two sites at Auckland International Airport and one approximately $350 \mathrm{~km}$ away at the Port of
Napier). A total of 900 plastic $60 \mathrm{ml}$ vials were placed in the field. The 900 vials were separated into 450 control and 450 treatment vials and were divided equally (150 control and 150 treatment) between the three field sites. The control vials were the current trap type used during the annual NIAS (a vial with a food attractant only), while the treatment vials were control vials with the addition of a sticky surface (Yellow fly paper - Russell IPM Ltd. UK.) on which ants could be trapped. The sticky surface comprised ca $10 \%$ of the vial wall surrounding 30\% of the food-baits. Non-sticky (control) and sticky (treatment) vials were placed out as paired replicates by placing one of each side by side, held together by a rubber band horizontally on the ground (Figure 1). Fifty replicates of a sticky and non-sticky pair testing the three different food baits were tested at each field site (total of 150 pairs). The vials contained either (1) sausage meat and peanut butter with soya bean oil smeared $1 \mathrm{~cm}$ apart along the inner edge of the vial (protein), (2) 30\% refined sugar in water on cotton wool (sugar) or (3) a combination of the two (combination). Both traps within a pair contained the same food attractant.

Vials were deployed and subsequently recovered by contractors following modified NIAS protocols as below. In this trial, one of each of the three food types was placed within each cell of a $15 \mathrm{~m} \times 15 \mathrm{~m}$ grid, with the constraint that no vial be placed within $2 \mathrm{~m}$ of another. Bait vials were laid within areas of favoured ant habitat, such as building and vegetation margins. Trials were conducted when environmental conditions were favourable for maximum ant recruitment $\left(20-25^{\circ} \mathrm{C}\right.$ air temperature, under dry conditions at the start of the trial) between 09:30 and 14:00. Lids were put on the vials to prevent ants escaping when they were collected $2 \mathrm{~h}$ after placement. All vials were retrieved for inspection and all ant specimens were identified to species by FBA Consulting (www.fbaconsulting.co.nz).

The effect of the sticky surface on the presence of ants in the traps was analysed using a paired t-test. Data were pooled and chi-square analysis was performed on the count data of 


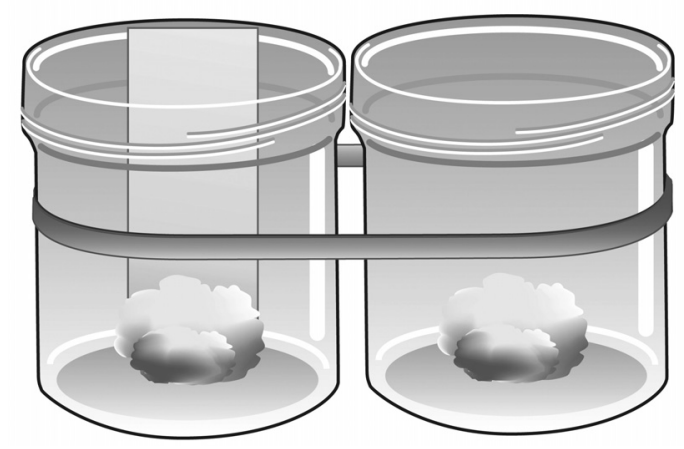

Figure 1 Illustration of trial setup. Two vials (55 mm long $\times 40 \mathrm{~mm}$ diameter) held together by a rubber band and placed horizontally on the ground. In this case the carbohydrate (30\% sugar in water on a cotton ball) trial is shown, with the treatment vial containing the sticky surface on the left and control on the right.

number of vials with multiple ant species present in treatment compared with control vials, as well as the effect of food on the number of traps with ants. Furthermore, the distribution of the individual species between the different food baits was assessed using chi-square tests. An ANOVA on $\log _{10}(x+1)$ count of ants in vials was conducted to determine the effect of food type on the number of ants trapped. All analyses were performed using Minitab 15.

\section{RESULTS}

The 900 vials represented $<2 \%$ of the vials placed during the $2007 / 08$ NIAS (47,765 vials). Just under half of the 900 traps contained ants at the time of collection, with $216(48 \%)$ of the treatment and 197 (44\%) of the control traps capturing at least one ant species. Five of the possible 39 ant species already established in the country (Landcare Research 2010) were trapped: Nylanderia sp. (formerly Paratrechina sp. (LaPolla et al. 2010)), Iridomyrmex sp., Pheidole rugosula Forel, Ochetellus glaber (Mayr) and Tetramorium grassii Emery. All species were trapped in both trap types and at all of the food sources. The majority of the traps were occupied by Nylanderia sp. (193), Iridomyrmex sp. (163) and Ph. rugosula
(71), although the abundance of individuals caught was greatest for Ph. rugosula (3487), Iridomyrmex sp. (2403) and then Nylanderia sp. (2320).

There was no difference between the non-sticky and the sticky surface vials in the number of traps retrieved with ants $(t=0.66$, $\mathrm{df}=899, \mathrm{P}=0.512)$. However, a greater proportion of sticky surface traps with ants had multiple species present at the time of retrieval $(0.125)$ than control traps $(0.025) ; 27$ and 5 traps respectively $\left(\mathrm{X}^{2}=15.13, \mathrm{df}=1, \mathrm{P}<0.001\right)$. Three treatment traps contained three species: two traps with a Nylanderia sp., Iridomyrmex sp. and $P h$. rugosula combination and one with Nylanderia sp., Iridomyrmex sp. and O. glaber present together.

Trap catch was significantly influenced by food type $(\mathrm{P}=0.034)$ with 3768 individuals trapped in the combination traps, 2976 in the protein and 1777 in the sugar traps. There was also a significant difference in the number of traps that caught ants for each food offered $\left(\mathrm{X}^{2}=14.77, \mathrm{df}=1, \mathrm{P}=0.001\right)$. Fifty-seven percent of the combined food traps captured ants, while $44 \%$ and $36 \%$ were trapped in the protein- and sugar-baited traps respectively (Figure 2a). Both tests ranked bait efficacy from highest to lowest as: combination $>$ protein $>$ sugar traps. There was no food preference for Nylanderia sp. (Figure 2c), but Iridomyrmex sp. and Ph. rugosula (Figure 2b \& d) showed distinct food preferences for combination and protein baits, respectively $(\mathrm{P}<0.001)$. Too few traps caught $O$. glaber and T. grassii (12 and 6 respectively) to reliably predict a food preference based on presence in a food-baited trap.

\section{DISCUSSION}

The proportion of multiple species caught by the sticky trap system was five times greater than for the conventional trap used for surveillance. Species diversity was increased at the traps where competitive exclusion effects were removed, confirming the value of this sampling approach.

The ants did have unimpeded access to the food source, whereby individuals could access 

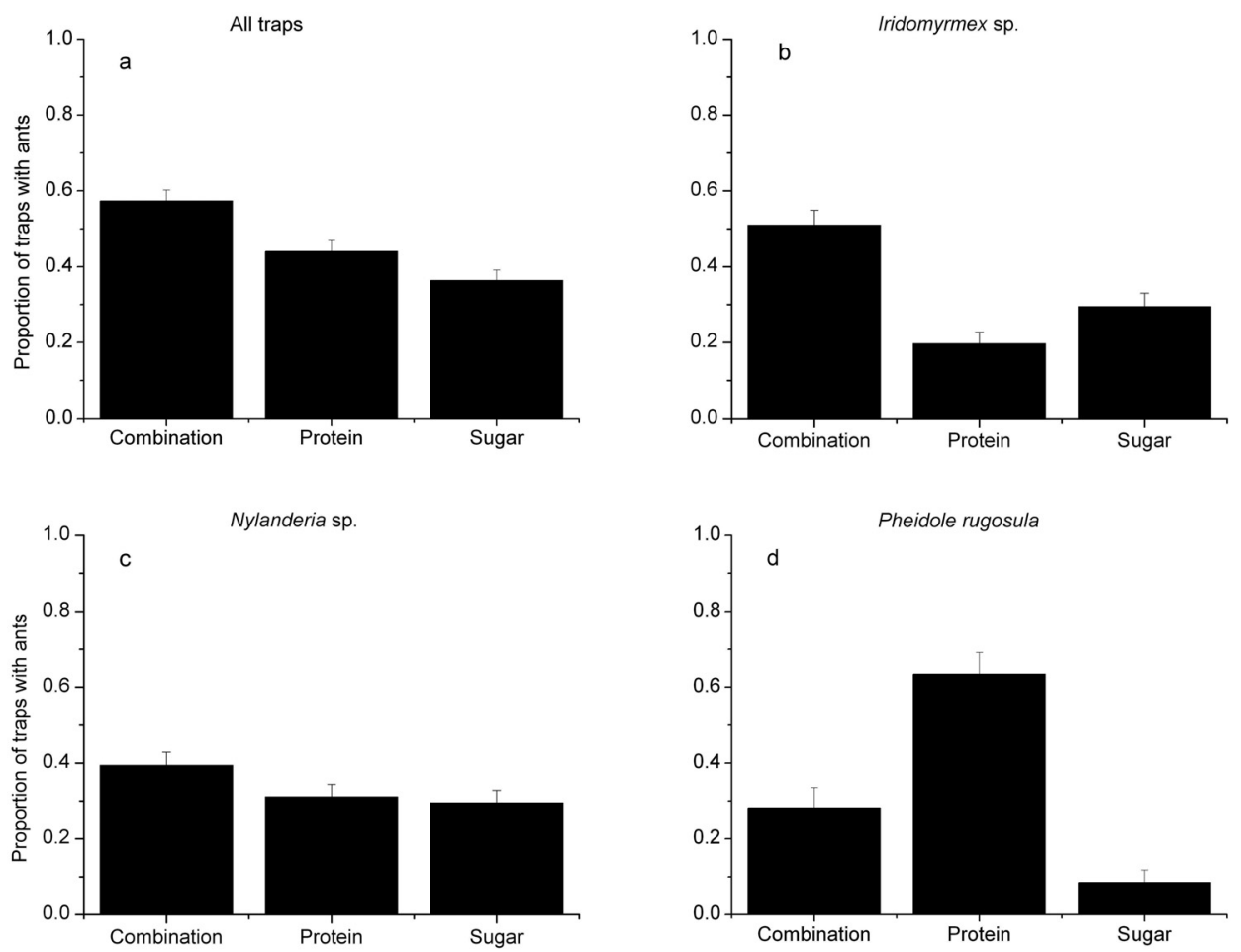

Figure 2 Proportion of traps returned with ants for each food source. Data are presented for all species (a) or for the distribution of individual species across the different food sources (b-d).

$\sim 70 \%$ of the food without needing to touch or cross the sticky surface. This may have led to the lower than desired multiple species catch rate. Species that employ a single recruitment and retrieval foraging strategy or are cryptic in nature rather than recruiting en masse to food sources could have been missed by this trap design, including NIAS target species that may be behaviourally subordinate or low in abundance (Sagata \& Lester 2009).

Food dominance can be influenced by temperature (Cerdá et al. 1997; Stringer et al. 2007). Hence traps with sticky surfaces could be more effective and trap more species over a longer period of time such as $24 \mathrm{~h}$, over which period the composition of actively foraging species can change (Wilson 1971). Odours also influence ant behaviour including orientation behaviour (Wolf \&Wehner 2000) and attraction to pitfall traps (Stanley et al. 2008). It is likely that the combination food had a richer suite of food odours that indicated the presence of multiple food type rewards. This is more likely to satisfy temporally variable nest dietary requirements than single food types, leading to increased discovery or recruitment, thus a greater proportion of traps with ants. However, this was not the case for Ph. rugosula, which appeared to prefer the protein-based food source over the combination and sugar baits.

The combination food source was the most attractive. Results suggest that a combination of the current protein and sugar food sources used in NIAS will attract these five species. However, as demonstrated by Ph. rugosula other ant species may not prefer a protein and sugar combination food source, thus may be missed if one food source is used, especially if there is not another less desirable food source to move on to if displaced by another species (Palmer 2003). 
The addition of a sticky surface acting as a passive trap appeared to reduce the impact of competitive exclusion on species presence in the vials by trapping a wider sample of the different ant species to attend the food sources. A comparison of ants arriving to baits but not getting trapped with actual trap catch of ants in traps is warranted to determine the efficiency of this trapping system. Furthermore, the type of sticky surface and its placement within the trap should be investigated to maximise the detection of additional ant species. The development and refinement of ant survey techniques should enhance surveillance sensitivity, thus increasing the chance of trapping new ant incursions at an early stage. It will also aid in the delimitation of established species adding to its value as a tool for surveillance managers.

\section{ACKNOWLEDGEMENTS}

This work was partially funded by the New Zealand Foundation for Research, Science and Technology through Contract C02X0501, the Better Border Biosecurity (B3) programme (www. b3nz.org). We would like to thank MAFBNZ and AsureQuality staff for assisting in data collection and John Kean for comments improving this manuscript.

\section{REFERENCES}

Abbott KL, Green PT 2007. Collapse of an ant-scale mutualism in a rainforest on Christmas Island. Oikos 116: 1238-1246.

Abbott KL, Greaves SNJ, Ritchie PA, Lester PJ 2007. Behaviourally and genetically distinct populations of an invasive ant provide insight into invasion history and impacts on a tropical ant community. Biological Invasions 9: 453-463.

Abril S, Oliveras J, Gomez C 2007. Foraging activity and dietary spectrum of the Argentine ant (Hymenoptera : Formicidae) in invaded natural areas of the northeast Iberian Peninsula. Environmental Entomology 36: 1166-1173.
Cerdá X, Retana J, Cros S 1997. Thermal disruption of transitive hierarchies in Mediterranean ant communities. Journal of Animal Ecology 66: 363-374.

Charles JG, Suckling DM, Allan DJ, Froud KJ, Dentener PR, Connolly P, Verberne H 2002. The distribution of Argentine ants in New Zealand: Can a ten-year old decision not to eradicate be re-visited? In: Goldson SL, Suckling DM ed. Defending the green oasis: New Zealand biosecurity and science. New Zealand Plant Protection Society, Lincoln, New Zealand. Pp. 109-124.

Crooks JA 2005. Lag times and exotic species: The ecology and management of biological invasions in slow-motion. Ecoscience 12: 316-329.

Crooks JA, Soulé ME 1999. Lag times in population explosions of invasive species: causes and implications. In: Sandlund OT, Schei PJ, Viken $\AA$ ed. Invasive Species and Biodiversity Management. Kluwer Academic Publishers, Dordrecht, The Netherlands. Pp. 103-125.

Davidson DW 1998. Resource discovery versus resource domination in ants: a functional mechanism for breaking the trade off. Ecological Entomology 23: 484-490.

Delabie JHC, Fisher BL, Majer JD, Wright IW 2000. Sampling effort and choice of methods. In: Agosti D, Majer JD, Alonso LE, Schultz TR, ed. Ants: Standard methods for measuring and monitoring biodiversity. Smithsonian Institution Press, Washington, USA. Pp. 145-154.

Fellers JH 1987. Interference and exploitation in a guild of woodland ants. Ecology 68: 1466-1478.

Hulme PE 2006. Beyond control: wider implications for the management of biological invasions. Journal of Applied Ecology 43: 835-847.

Landcare Research 2010 http://www. landcareresearch.co.nz/research/biocons/ invertebrates/Ants.asp (accessed 14 April 2010). 
LaPolla JS, Brady SG, Shattuck SO 2010. Phylogeny and taxonomy of the Prenolepis genusgroup of ants (Hymenoptera : Formicidae). Systematic Entomology 35: 118-131.

McGlynn TP 1999. Non-native ants are smaller than related native ants. American Naturalist 154: 690-699.

McGlynn TP 2000. Do Lanchester's laws of combat describe competition in ants? Behavioral Ecology 11: 686-690.

Nendick D, Sarty M, O'Conner S, Rechenberg G, Skucek R, Vanderwoude C, Weston G 2006. Pacific off-shore container management programme. In: Biosecurity Magazine, Issue 70. Biosecurity New Zealand, Wellington, New Zealand. Pp. 4-6.

O'Dowd DJ, Green PT, Lake PS. 2003. Invasional 'meltdown' on an oceanic island. Ecology Letters 6: 812-817.

Palmer TM 2003. Spatial habitat heterogeneity influences competition and coexistence in an African Acacia ant guild. Ecology 84: 2843-2855.

Sagata K, Lester PJ 2009. Behavioural plasticity associated with propagule size, resources, and the invasion success of the Argentine ant Linepithema humile. Journal of Applied Ecology 46: 19-27.

Simberloff D 2006. Invasional meltdown 6 years later: important phenomenon, unfortunate metaphor, or both? Ecology Letters 9: 912-919.

Simberloff D, Gibbons L 2004. Now you see them, now you don't! - population crashes of established introduced species. Biological Invasions 6: 161-172.
Stanley M, Ward D, Harris R, Arnold G, Toft R, Rees J 2008. Optimizing pitfall sampling for the detection of Argentine ants, Linepithema humile (Hymenoptera : Formicidae). Sociobiology 51: 461-472.

Stringer LD, Lester PJ 2008. The ant community response to the arrival of Monomorium sydneyense Forel (Hymenoptera : Formicidae) at Sulphur Point, Tauranga, New Zealand. New Zealand Journal of Zoology 35: 53-61.

Stringer LD, Haywood J, Lester PJ 2007. The influence of temperature and fine-scale resource distribution on resource sharing and domination in an ant community. Ecological Entomology 32: 732-740.

Stringer LD, Stephens AEA, Suckling DM, Charles JG 2009. Ant dominance in urban areas. Urban Ecosystems 12: 503-514.

Ward DF, Green C, Harris RJ, Hartley S, Lester PJ, Stanley MC, Suckling DM, Toft RJ 2010. Twenty years of Argentine ants in New Zealand: past research and future priorities for applied management. New Zealand Entomologist 33: 68-78.

Whitney KD, Gabler CA 2008. Rapid evolution in introduced species, 'invasive traits' and recipient communities: challenges for predicting invasive potential. Diversity and Distributions 14: 569-580.

Wilson EO 1971. The insect societies. Belknap Press, Cambridge, MA. 548 p.

Wolf H, Wehner R 2000. Pinpointing food sources: Olfactory and anemotactic orientation in desert ants, Cataglyphis fortis. Journal of Experimental Biology 203: 857-868. 